\title{
Editorial
}

\section{Revista Ensaio número 47}

Apresento, com muita satisfação, o quadragésimo sétimo número da Revista Ensaio, que corresponde ao segundo trimestre do ano em curso, na certeza de estar oferecendo a nosso público leitor mais uma colaboração voltada para os educadores em geral e, especificamente, aos estudiosos de Avaliação e de Políticas Públicas em Educação.

presente número traz, em seus sete textos, a produção intelectual de treze pesquisadores abordando, em enfoques diversificados, o tema central da revista, contribuindo, assim, para a disseminação e democratização dos conhecimentos decorrentes de seus estudos.

No artigo Educação Superior no século XXI e a Reforma Universitária Brasileira, Arthur Roquete de Macedo, Ligia Maria Vettorato Trevisan, Péricles Trevisan e Caio Sperandeo de Macedo discutem, considerando a evolução e as características do Sistema Brasileiro de Educação Superior, as bases de uma efetiva reforma dessa Educação, relacionando a adequação deste Sistema ao enfrentamento dos desafios da sociedade do conhecimento no Brasil de hoje e as possíveis soluções advindas da referida adequação.

No artigo O PDI como referente para a Avaliação de Instituições de Educação Superior: lições de uma experiência, Stella Cecília Duarte Segenreich, descreve e analisa a experiência da organização do Plano de Desenvolvimento Institucional (PDI) em uma Universidade do Rio de Janeiro, com o objetivo de demonstrar que, quando este plano é resultado de uma construção coletiva, se impõe, naturalmente, como fio condutor para qualquer avaliação.

No artigo de Vera Vergara, Wally Chan e Lucia Siano intitulado Uma competência emergente da gestão escolar: a animação cultural, as autoras defendem a escola como o espaço público, escolhido pela sociedade para, através de suas ações, atingir seus objetivos educacionais, situando a figura do animador cultural como o realizador de um trabalho de Educação Popular.. Este texto apresenta uma proposta da mudança de eixo da animação cultural nas escolas brasileiras 
Maria José Casa-Nova, no artigo (I) Migrantes, diversidades e desigualdades no Sistema Educativo Português: balanços e perspectivas, nos envia um olhar, sociologicamente informado no que concerne à situação portuguesa, quanto ao domínio das políticas educativas públicas e pesquisas relacionadas com o Sistema Educativo,isto é, a (i)migração como tentativa de construção de uma educação intercultural

Na sessão Página Aberta, Álvaro Chrispino, no texto Ensino Público Gratuito: flexibilidades e desvios, aborda o ensino público gratuito e os conceitos do princípio constitucional de gratuidade, esclarecendo como este princípio se aplica ao Ensino Público e apontando como o mesmo se apresenta no texto da LDB e, também,algumas contradições observadas.

Adriana Roseli Wunsh Takahashi, autora do texto A Descentralização como Política Pública no setor educacional: uma análise dos impactos em Escolas Públicas no Município de Curitiba-PR, apresentado como Pesquisa em Síntese, relata a análise do impacto da política de descentralização na vida escolar, identificando, em duas escolas da rede municipal de Curitiba, no Paraná,. as estratégias adotadas para gerenciar os recursos financeiros recebidos e seu impacto na atividade docente.

Em Informes e Participações, Ana Carolina Letichevsky, Marley Maria Vellasco, Ricardo Tanscheit e Reinaldo Castro Souza no texto La Categoria Precisión em la Evaluación y en la Meta evaluación: Aspectos Prácticos y Teóricos, apresentam uma concepção moderna de avaliação e de meta-avaliação, discutindo o papel da última para assegurar a qualidade de um processo avaliativo em seus diferentes enfoques, a partir das categorias de uma verdadeira avaliação: utilidade, viabilidade, ética e precisão.

Espero e acredito que estes textos, traduzindo o pensamento educacional de alguns estudiosos contemporâneos, possam contribuir com nosso público leitor na busca de alternativas para a ampliação de conhecimentos dos temas abordados nesta edição, bem como, promover uma reflexão sobre aspectos de importância relevante para a interpretação do contexto educacional.

Carlos Alberto Serpa de Oliveira 